\title{
Die Behandlung der Syphilis mit Serum mercurialisirter Thiere.
}

\author{
Von \\ Dr. B. Tarnowsky, und \\ Prof. emer. \\ Dr. S. Jakowlew, \\ Assistent \\ der syphilodolog. Klinik an der Kaiserlichen medicin. Akademie zu St. Petersburg.
}

Im vorigen Jahr, auf dem VI. russischen Pirogow'schen Aertztecongress in Kijew hat Einer von uns über negative Resultate bei Serumbehandlung syphilisirter Pferde berichtet, und dabei wurde die Ansicht ausgesprochen, dass vielleicht Mercurialisirung der Thiere dazu beitragen werde, dass deren Serum einen günstigeren Einfluss auf syphilitisch erkrankte Menschen gewinne. ${ }^{\mathbf{1}}$ )

$\mathrm{Zu}$ diesem Zweck mercurialisirten wir drei Füllen im Alter von 14-18 Monaten, indem wir denselben 0.18-0.24 Calomel, in Oleum vaselin. suspendirt, unter die Haut einspritzten. Die Injectionen wurden zwei- bis dreimal wöchentlicb gemacht, mit Unterbrechungen, die für die Blutentziehungen nothwendig waren; sie wurden durchschnittlich $2^{1 /},{ }_{q}$ Monate mit Quecksilber behandelt, bekamen im Ganzen 16-30 Einspritzungen, es wurden ihnen demnach $4 \cdot 0-6 \cdot 0$ Calomel einverleibt. An allen drei Thieren stellten sich zum Schluss der Einspritzungen, gerade zu der Zeit, als ihnen Blut zur Gewinnung von Serum entnommen wurde, deutliche Anzeichen von Stomatitis mercurialis ein.

Das Serum wurde im Institut für Experimental-Medicin von Dr. Dshergowski gewonnen. Er stellte auch Prüfungen

1) Prof. B. Tarnowsky. Serotherapie als Heilmittel der Syphilis. Archiv für Dermatologie und Syphilis. Bd. XXXVI., H. 1-2. 1896. 
des Serums auf Quecksilber an, die das Vorhandensein dieses Metalls darin (von 0.0001-0.0003) nachwiesen.

Von 13 Kranken, die mit diesem Serum behandelt wurden, zeigte der Harn bei 5 während der Behandlung Quecksilberspuren. ${ }^{1}$ )

Ausser diesem Serum, welches ohne Zufügung von Phenol zubereitet war, versuchten wir auch solches, das von Pferden stammte, welche von Dr. Dshergowski am Institut für Experimental-Medicin durch Injectionen von mit Phenol $(0.5$ Phenol auf $10 \mathrm{Ccm}$. Serum) versetztem Hydrarg. salicyl. mercurialisirt worden waren.

Wrr verfügen im Ganzen über 16 Beobachtungen; 13 dieser Kranken wurden mit dem Serum der von uns mercurialisirten Pferde behandelt, und 3 mit dem von Dr. Dshergowski gewonnenen Serum.

Alle Patienten, die dieser Behandlung unterzogen wurden, hielten sich in besonderen Räumen auf, getrennt von den mit Quecksilber behandelten; sie erhielten kräftige Nahrung und bekamen 2mal wöchentlich warme Bäder; auf etwaige ulcerirte Flächen wurde Glycerin mit Wasser applicirt.

Das Serum wurde in der Quantität von $10-20$ Ccm. drei- bis viermal wöchentlich mit den üblichen Vorsichtsmassregeln in die Rückengegend injicirt.

Durchschnittlich bekam jeder Patient 17 Injectionen (Minimum 6, Maximum 26) im Betrag von $183 \mathrm{Ccm}$.

Von den 16 Patienten hatten 11 Frühformen von Syphilis, und 5 standen in der gummösen Periode. Von den ersteren 11 wiesen 7 im Beginn der Behandlung ausschliesslich Primärerscheinungen auf, d. h. Primärsclerose mit Inguinaladenitis (Beobacht. I, II, V, VI, VII, VIII, X). Diese 7 Patienten waren kräftige junge Leute, durchschnittlich 23 Jahre alt; sie kamen (durchschnittlich) am 12. Tag (Minimum 4, Maximum 30) nach Auftreten der Primärsclerose auf die Klinik und hatten früher keine Quecksilber- oder Jodbehandlung durchgemacht.

1) Nach Dr. Witz's Methode; vgl. Ssukow, Ueber Quecksilberausscheidung im Harn. 1886. (Russisch.) 
In allen diesen 7 Fällen wurde durch die Serumeinspritzungen nicht nur der Entwicklung der secundären Erscheinungen nicht vorgebeugt, sondern auch der Verlauf derselben in Gestalt von fleckigen, papulösen Syphiliden, schleimigen Papeln, Polyadenitis etc. blieb dabei im Allgemeinen unverändert.

Aber nicht nur das; es wurde auch jeglicher Einfluss der vorgenommenen Behandlung auf eine nachweisbare Verminderung der Intensität des ersten Ausschlags und der Prodromalerscheinungen vermisst, insbesondere der Kopfschmerzen, die in zwei Fällen (Beob. V und VII) so heftig waren, dass die Kranken an Schlaflosigkeit litten, rasch an Gewicht abnahmen und schwach wurden.

Ausserdem wurde in keiner einzigen der betreffenden Beobachtungen durch die Serumbehandlung das Auftreten des ersten Ausschlags (vom Beginn der Primärsclerose gerechnet) verzögert, wie das bei Anwendung von Quecksilber, Jod oder Diaphorese der Fall ist.

Die Periode der sogen. zweiten Incubation betrug in den 7 Fällen durchschnittlich $5 \frac{1}{2}$ Wochen.

Ferner wurde, wie gesagt, bei der von uns erprobten Behandlungsweise keine Abweichung des Verlaufs und der regelmässigen Entwicklung der consecutiven Polyadenitis wahrgenonmen.

Anscheinend wurde der Verlauf der Syphilide einigermassen durch die Behandlung beeinflusst, aber nicht durch das Serum selbst, sondern durch eine Nebenerscheinung der Serotherapie, und zwar durch Steigerung der Temperatur, die in Folge dẹr Einspritzungen entsteht.

Sobald die Temperatur eines Patienten merkbar stieg, eventuell wenn sie mehrere Tage hintereinander erhöht blieb, so hielt die Eruption ein oder begann sogar abzublassen; wenn aber die Einspritzungen nicht mehr Fiebererscheinungen bewirkten, so nahm der Ausschlag seinen früheren Verlauf.

Im Allgemeinen muss gesagt werden, dass in den in Rede stehenden 7 Fällen der Verlauf der Primärerscheinungen, der Proutromalperiode und der ersten Eruption durch Einverleibung des Serums nicht in günstigem Sinne rerändert wurde. 
Die anderen $4 \mathrm{im}$ Alter von 20-40 (durchschnittlich 30) Jahren stehenden Patienten (Beob. III, IV, IX, XI) boten im Beginn der Serumbehandlung früher secundäre syphilitische Erscheinungen dar: bei dreien fing gerade die erste Eruption an, und bei einem (1 $1 \%$ Jahre nach Beginn der Erkrankung) bestand ein secundäres papulo-pustulöses Syphilid.

Diese Patienten waren ebenfalls vor ihrer Aufnahme in die Klinik weder mit Quecksilber, noch mit Jod behandelt worden.

In einem dieser Fälle (Beobachtung IV) wurden die Seruminjectionen von den ersten Tagen des Auftretens des maculösen Syphilids an gemacht, und trotzdem waren im weiteren Verlauf des Ausschlags sowohl, als auch im Eintritt anderer secundärer Erscheinungen keine bemerkbaren Abweichungen wahrzunebmen. Nach 25 Einspritzungen, entsprechend der Einverleibung von $290 \mathrm{Ccm}$. Serum, hatte Patient Sclerose am Ort der Primäraffection, ausgeprägte Polyadenitis, maculöses Syphilid am ganzen Körper und an den Extremitäten, stellenweise zerstreute trockene Papeln, schleimige Papeln am Mund, Alopecie etc.

In einem anderen ganz ähnlichen Fall (Beob. IX) wurden die Seruminjectionen begonnen, als eben ein erythematöses Syphilid sich einzustellen anfing. Nach 50 Tagen, im Verlauf derer Patient 26 Einspritzungen zu je $10 \mathrm{Ccm}$. erbalten hatte, war noch ein schwach ausgeprägtes maculöses Syphilid am Körper vorhanden.

Auch im dritten Fall (Beob. III), wo die SerumbehandIung bei der ersten Eruption in Gestalt eines polymorphen Syphilids (Flecken und geringfügige pustulöse Papeln) vorgenommen wurde, war das Ergebniss ebenso ungünstig. Patient bekam im Verlauf von 52 Tagen 25 Einspritzungen mit Einführung von 280 Ccm. Serum, und hatte danach am Rumpf und an den Extremitäten das nämliche Syphilid, stellenweise breite Papeln, pustulöse Papeln etc.

Also war in diesen drei Beobachtungen, in welchen die Serumbehandlung ganz im Beginn der ersten Eruption stattfand, der weitere typische Verlauf der syphilitischen Manifestationen unverändert geblieben, und die Krankheit schritt im 
Die Behandlung der Syphilis mit Serum mercurial. Thiere. 229

Allgemeinen ebenso vor, wie es in nicht behandeiten Fällen geschieht.

Die Beobachtung an dem Kranken mit frisch aufgetretenem secundärem Syphilid zeugt noch deutlicher von dem Mangel günstiger Beeinflussung des allgemeinen Krankheitsverlaufs durch das Serum, und zugleich offenbart sich hier die Bedeutung gesteigerter Temperatur für die syphilitischen Hautaffectionen.

Ein Pat. (Beob. XI) begann die Behandlung bei bestehendem papulo-pustulösen Syphilid am Rumpf und an den Extremitäten. Im Verlauf von 36 Tagen bekam er 15 Injectionen mit $150 \mathrm{Ccm}$. Serum. Die sehr schmerzhaften Einspritzungen bewirkten anfänglich eine Steigerung der Temperatur, welche 20 Tage lang (von der 4 . bis zur 10. Einspritzung) beständig abnorm hoch blieb (38.0-39.6 ${ }^{0}$ Abends). Während dieser Zeit begann das Syphilid einzutrocknen, die Krusten fielen ab, die Papeln schuppten, und nach 10 Einspritzungen blieben nur Pigmentflecke vom Syphilid zurück. Doch die zehnte und die weiteren Injectionen bewirkten nicht mehr Fieberzustände, und nach 9 Tagen stellte sich, ungeachtet der in dieser Zeit gemachten neuen 5 Einspritzungen, eine recidivirende Roseola an den Oberextremitäten ein.

Indem wir zu der Einwirkung mercurialisirten Serums auf die gummöse Periode der Syphilis übergehen, müssen wir vorerst bemerken, dass noch vor dem Beginn unserer Untersuchungen Dr. Wreden ${ }^{\mathbf{1}}$ ) in Kijew fünf Beobachtungen mitgetheilt hat, in denen die Behandlung mit mercurialisirtem Serum von Dr. Dshergowski gummöse Bildungen mit äusserst glänzendem Erfolg beeinflusst haben soll. Nach 2-3 Injectionen zu je $10 \mathrm{Ccm}$. kamen Knochenschmerzen zum Schwund, Periostitiden zur Resorption, ausgedehnte Geschwüre zur Verheilung, kurz, die Kranken wurden rasch besser und genasen.

Von unseren 5 Fällen gummöser Syphilis waren 4 mit acquirirter Syphilis behaftet und einer mit hereditärer.

') Dr. Wreden, Ergebnisse der ersten Versuche mit Serotherapie in Kijew. Bolnitschnaja Gazeta Botkina, 1895. (Russich.) 
Die Kranken mit acquirirter gummöser Syphilis waren junge Leute im Alter von 16-30 (durchschnittlich 23) Jahren und hatten sich vor 5 bis 8 (durchschnittlich $6 \%$ ) Jahren vor Beginn der Serumbehandlung inficirt. Bei Aller. bestanden ulcerirte Gummata an verschiedenen Körperstellen, und vor Aufnahme in die Klinik waren sie in verschiedenartiger Weise behandelt worden, auch mit Quecksilber; an Einigen (Beob. XIII und XIV) waren noch erkennbare Spuren der Mercurialbehandlung nachweisbar, indem ihr Harn vor Beginn der Serumeinspritzungen Quecksilber enthielt.

In den ersten zwei Fällen (Beob. XII und XIII) äusserte sich die Wirkung der Serumbehandlung darin, dass zum Schluss der Cur neue gummöse Knötchen auftraten.

In der folgenden Beobachtung (XIV) begann das gummöse Geschwür im Anfang der Behandlung zu verheilen, aber nach 6 Serumeinspritzungen nahm es rasch zu, wurde schmerzhaft, und der Allgemeinzustand des Patienten verschlimmerte sich derartig, dass wir uns veranlasst sahen, eine gemischte Quecksilber-Jodbehandlung vorzunehmen, die glänzenden Erfolg hatte.

Der letzte Kranke (Beob. XV), ein 16jähriger Jüngling, hatte ein knotiges Syphilid, und dasselbe blieb trotz 15 Injectionen $(150 \mathrm{Ccm}$. Serum) ohne wahrnehmbare Veränderung. In Anbetracht dieser Erfolglosigkeit verordneten wir dem Kranken Quecksilber-Jodbehandlung mit dem üblichen raschen und gïnstigen Resultat.

Schliesslich konnten wir in einem Fall hereditärer Syphilis (Beob. XVI) die Einwirkung des Serums auf Knochenschmerzen bei gummöser Osteoperiostitis erproben. Patient, ein Knabe, der wie 9jährig aussieht, thatsächlich aber 14 Jahre alt ist, klagte über heftige nächtliche Schmerzen in den Knochen der Ober- und Unterextremitäten, die ihn nicht schlafen liessen. An den Knochen der Vorderarme und Unterschenkel (en lame de sabre) waren gummöse Neubildungen in verschiedenen Entwicklungsstadien zerstreut. Im Verlauf von 28 Tagen bekam Patient 7 Einspritzungen zu je $10 \mathrm{Ccm}$. Dieselben waren äusserst schmerzhaft und hatten Fiebererscheinungen und dann einen Purpuraausschlag mit heftiger Anschwellung der Axillardrüsen zur Folge. Nach 7 Einspritzungen waren die nächtlichen 
Die Behandlung der Syphilis mit Serum mercurial. Thiere. 231

Knochenschmerzen noch immer da, mehrere gummöse Knoten an den Unterschenkeln waren erweicht und im Begriff aufzubrechen; der Allgemeinzustand hatte sich verschlimmert, und in Anbetracht der zunehmenden Schwäche und der Erfolglosigkeit der Serumbehandlung verordneten wir dem Patienten Quecksilbereinreibungen und Jodkali innerlich. Danach begann er sich rasch zu erholen.

Aus Vorstehendem ist ersichtlich, dass wir die Behandlung von Serum mercurialisirter Pferde bei allen hauptsächlichsten Momenten des Verlaufs der Syphilis erprobt haben.

Diese Behandlung wurde rorgenommen: in den ersten Tagen nach Auftreten der Primärsclerose (Beob. VI und VII), bei völliger Entwicklung derselben in Begleitung ron Adenitis (Beob. I, II, V, VIII und X), im Beginn der ersten Eruption (Beob. III, IV und IX), in der Blüthezeit der secundären Periode der Syphilis (Beob. XI) und schliesslich in der gummösen Periode acquirirter (Beob. XII, XIII, XIV, XV) und hereditärer Syphilis (Beob. XVI).

Als die Serumbehandlung in der Initialperiode der Syphilis ausgeführt wurde, blieb der weitere Krankheitsverlauf ohne günstige Veränderung. Die consecutiven syphilitischen Erscheinungen entwickelten sich zu der nämlichen Zeit und mit eben solcher Intensität, wie in nicht behandelten Fällen.

Bei Verordnung dieser Behandlung im Prodromalstadium und beim Beginn der ersten Eruption, wurde das Auftreten derselben nicht auf rehalten und ihre Manifestation nicht abgeschwächt.

Auch in der secundären Periode der Syphilis erwiesen sich die Seruminjectionen als machtos, indem es nicht gelang, dem Eintritt eines frühen Recidivs vorzubeugen oder selbiges aufzuschieben, und da es während der Behandlung selbst sich einstellte.

In der gummösen Periode wurden sowohl bei erworbener als auch hereditärer Syphilis weder Knochenschmerzen durch Seruminjectionen vertrieben, noch die Resorption vorhandener Gummata beschleunigt, noch die Bildung neuer Knötchen aufgehalten. 
In Anbetracht derartigen Verhaltens gelangen wir bezüglich der Syphilisbehandlung mit mercurialisirtem Serum zu einem unbedingt negativen therapeutischen Ergebniss.

Abgesehen davon erweisen unsere Beobachtungen mit grösserer Deutlichkeit, als es früher der Fall war, die äusserst ungünstige Beeinflussung des Gesammtzustands der Patienten durch die in Rede stehende Behandlungsweise. Von den $16 \mathrm{Be}$ obachtungen wurden in 13 Fällen durch die Seruminjectionen Fieberzustände bewirkt, wobei die Körpertemperatur um 1·2 und 3 Grad stieg.

In neun Fällen war das Fieber von Erythem oder Purpura-Ausschlag begleitet; in sechs davon wurde Albuminurie constatiri, und in fünf klagten die Kranken über Schmerzen in den Gelenken, Muskeln und über beträchtliche schmerzhafte Anschwellungen der Axillardriisen.

Endlich nahm in der grösseren Hälfte der Beobachtungen (in 9 Fällen) das Körpergewicht der Kranken zum Schluss der Behandlung ab, und in einem Fall (Beob. V) sogar sehr bedeutend, fast um 5 Kilogramm.

Ausserdem hat Dr. Ssukow, Ordinator der Klinik, an den meisten der von uns mit mercurialisirtem Serum behandelten Patienten Blutuntersuchungen angestellt. Die Ergebnisse derselben, die von Dr. Ss u k o w in dessen Inanguraldissertation ${ }^{1}$ ) veröffentlicht sind, bestehen darin, dass die Blutmischung in allen Perioden der Syphilis unter dem Einfluss der Einspritzungen verschlechtert wird, und zwar nimmt die Anzahl der rothen und weissen Blutkörperchen ab; dabei verringert sich auffallend die Zahl der Entwicklungsformen weisser Blutkörperchen, während diejenige der ausgereiften unverändert bleibt oder sogar verhältnissmässig zunimmt; zugleich sinkt der Hämoglobingehalt und das specifische Gewicht des Blutes.

Also hat das von uns erprobte Serum mercurialisirter Pferde die theoretischen Anschauungen über Antitoxine und Antagonisten der Syphilis nicht bestätigt.

- ') Dr. N. W. Ssukow, Beiträge zur Serotherapie der Syphilis. Inaugural-Dissertation. St. Petersburg 1897 (Russisch.) 
Die Behandlung der Syphilis mit Serum mercurial. Thiere. 233

Die geringfügigen Quecksilbermengen, die dem Organismus zusammen mit dem Serum einverleibt werden, erwiesen sich als machtlos bezuiglich der Anregung der Resistenzfähigkeit des kranken Organismus. Dagegen hat sich die ungünstige Beeinflussung der Patienten durch das Serum selbst bei diesen unseren Untersuchungen deutlicher als früher offenbart.

Auf Grund vorstehender Angaben gelangen wir zu folgenden Schlüssen.

1. Einspritzungen von Serum mercurialisirter Pferde besitzen keine Heilwirkung gegenüber dem Verlauf der Primäraffection und auch der secundären (condylomatösen) und tertiären (gummösen) Periode der Syphilis.

2. Einführung mercurialisirten Serums vermittelst subcutaner Einspritzungen bewirkt in $4 / 5$ der Fälle Fiebererscheinungen, meistentheils in Begleitung ron Purpura-Ausschlag, Gelenk- und Muskelschmerzen, Albuminurie, Schwellung der Axillardrüsen und Abnahme des Körpergewichts.

3. Bei Einspritzungen mercurialisirten Serums wird an syphilitischen Patienten beständig Verarmung des Blutes beobachtet, in Folge von Verringerung der Anzahl rother und weisser Blutkörperchen, Abnahme des Hämoglobingehalts und des specifischen Gewichts des Blutes.

4. Aus der Gesammtheit der von uns bisher angestellten Untersuchungen geht hervor, dass weder Einspritzungen reinen Pferdeserums, noch solchen, welches von mercurialisirten und syphilisirten Füllen stammt, als Behandlungsmethode der Syphilis empfohlen werden können; sie müssen, im Gegentheil, vermieden werden, da der Organismus der Kranken durch Einverleibung des Thierserums geschädigt wird.

\section{Beobachtungen.}

I. A. A., 24jähriger Soldat, blond, kräftigen Körperbaus; Wuchs $165 \mathrm{Cm}$., Körpergewicht $61^{\circ} 6 \mathrm{Kilogramm}$. Er entdeckte ein Geschwür an seinem Geschlechtsglied am 18. Februar 1896, am 16. Tag post coitum; er war local mit Jodoform behandelt worden.

Er wurde am 1. März 1896 mit folgendem Status in die Klinik aufgenommen: am inneren Präputiumblatt in der Mittellinie ein granulirendes hartes Schankergeschwür, an dessen Basis charakteristische Sclerose; rechts am Rand der Glans penis eine charakteristische Schanker- 
erosion, ebenfalls mit indurirter Basis. In der rechten Inguinalgegend eine grosse harte Drüse; weitere Drüsen sind nicht durchaufühlen. Es wurden Umschläge aus Glycerin, zur Hälfte mit Wasser vermischt, verordnet.

2. März. Der Harn enthält kein Eiweiss. Es wurde die erste Einspritzung $(10 \mathrm{Ccm}$.) mercurialisirten Serums von Dr. Dshergowski mit $0.5 \%$ Phenol gemacht. Dieses Serum stammte, wie oben ausgeführt, von Pferden, die im Institut für Experimentalmedicin durch Injectionen von Hydrarg. salicyl. mercurialisirt waren. Vom 2. März bis zum 22. April wurden 25 Einspritzungen (280 Ccm.) carbolisirten mercurialisirten Serums gemarht. Die Körpertemperatur blieb Morgens fast die ganze Zeit normal, Abends aber stieg sie meistens auf $37.5-37.8^{\circ}$. Das Körpergewicbt schwankte zwischen $61^{\circ} 2$ und $62.8 \mathrm{Kg}$. Patient vertrug die Einspritzungen gut, ohne Complicationen. Die Syphiliserscheinungen verliefen in folgender Weise:

Am 9./III., nach 4 Einspritzungen, schwollen beide Axillardrüsen an; das Geschwür in der Mittellinie ist vernarbt, das andere granulirt.

13./III. Längs des Gliedes besteht verhärtete, schmale Lymphangoitis.

20./III. Nach 10 Einspritzungen sind beide Geschwüre vernarbt, unter Hinterlassung grosser Verbärtungen von knorpeliger Consistenz.

30/III. Nach 14 Einspritzungen hat sich die Lymphangoitis verringert; die Sclerosen und Drüsen bestehen unverändert.

6./IV. Nach 17 Einspritzungen. An beiden Rumpfseiten einige schwache Roseolaflecken, scharf umschriebene Röthe der Gaumenbögen und Uvula, opalescirende Plaques an der rechten Tonsilla. Keine Albuminurie.

13./V. Nach 20 Einspritzungen besteht an der Stella beider Geschwüre ausgeprägte Sclerose; an der Glans penis in der Nähe des Frenulum eine Papel. Die rechte Leistendrüse ist rund und hart, andere sind nicht durchzufühlen. Blasse Roseolaflecken an beiden Rumpfseiten. Eine Plaque an der rechten Tonsilla und eine Papel an der Unterlippe.

20./IV. Schwach angedeutete Roseola an den Seiten und am Unterleib.

22./TV. Nach 25 Einspritzungen. Zwej deutliche Sclerosen an Stelle der verheilten Geschwüre. Links am Präputialrand eine Plaque aus mehreren Papeln. Rechts eine harte Leistendrüse, links eine grosse verhärtete Axillardrüse, weiter keine. An Brust, Bauch und theilweise am Rücken zahlreiche schwache Røseolaflecken. Plaques an der rechten Tonsilla, eine kleine Papel an der Unterlippe und am After. Es werden Quecksilbereinreibungen zu $2 \cdot 0$ verordnet.

22./V. Nach 28 Einreibungen. Alle Erscheinungen sind verschwunden, mit Ausnahme einer geringfügigen Verhärtung an Stelle der verheilten Geschwüre und einer unbedeutenden Schwellung der rechten Leistendrüse. 
Die Behandlung der Syphilis mit Serum mercurial. Thiere. 235

Im Allgemeinen muss man sagen, dass die Einspritzungen carbolisirten Quecksilberserums keinø wahrnehmbaren Veränderung im Verlauf der Krankheit bewirkt haben. Die erste Eruption stellte sich zur üblichen Zeit, gegen 6 Wochen nach Auftritt des Primärgeschwürs ein, und ihre Ausbreitung ging wie in unbehandelten Fällen vor sich. Das maculöse Syphilid war allerdings etwas blass, doch das konnte durch die kleine abendliche Temperatursteigerung bedingt sein. Auch die Affection der Schleimhäute in Gestalt von Papeln zeugt von progressivem Verlauf der Krankheit, die durch die Serumbehandlung durchaus nicht aufgehalten wurde, während 28 Einreibungen alle Erscheinungen im Laufe eines Monats zum Schwund brachten.

II. K. J., 24jähriger Soldat, brünett, von gutem Körperbau; Wuchs $160 \mathrm{Cm}$., Körpergewicht $57.2 \mathrm{Kg}$. Er hatte am 22. Februar 1896 ein Geschwür an den Geschlechtstheilen entdeckt, 45 Tage post coitum.

Er wurde am 4. März 1896 mit folgenden Erscheinungen in die Klinik aufgenommen: Am inneren Blatt des Präputium rechts neben dem Frenulum ein ovales oberflächliches Geschwür mit Zerfall im Centrum und geringer Induration an der Basis; am Frenuluru ein anderes eben solches Geschwür. In der rechten Leistengegend eine kleine harte Drüse. An der Dorsalfläche beider Hände, an den Knien, an der Vorderfiäche der Unterschenkel, am rechten Oberschenkel und an der rechten Hinterbacke vereinzelter, mit perlmutierartigen Schuppen bedeckter Ausschlag von Psoriasis vulgaris. Allgemeinzustand gut. Kein Eiweiss im Harn. Localbehandlung mit Umschlägen aus Glycerin und Wasser.

Am 6. März 1896 wurde die erste Einspritzung (10 Ccm.) carbolisirten Quecksilberserums von Dr. Dshergowski vorgenommen. Die Injectionen wurden dreimal wöchentlich zu je $10 \mathrm{Cem}$. gemacht; nur die 5. Einspritzung enthielt $20 \mathrm{Ccm}$. Im Verlaufe der Zeit vom 6. März bis zum 26. April bekam Patient 25 Einspritzungen, wobei $260 \mathrm{Ccm}$. dieses Serums eingeführt wurden.

Die Körpertemperatur stieg nach der 2. und 3. Einspritzang auf $38 \cdot 1^{\circ}$, und nach der 8. auf $39^{\circ}$, wobei beträchtliche Albuminurie. An der Dorsalfäche der linken Hand im Gebiet des Carpo-radialgelenks verbreitete erythematöse Röthe mit Gelenkschmerzen, und an Bauch und Brust unregelmässige Erythemflecken mit bläulicher Verfärbung sich einstellten. Nach zwei Tagen versehwanden alle diese Erscheinungen spurlos, auch die Albuminurie. Aehnlicbe, doch etwas schwächere Erythemflecken stellten sich nach der 5. Einspritzung am Bauch und Vorderarm ein; sie hielten sich zwei Tage lang, fast obne Temperatursteigerung, und verschwanden ebenfalls. In der übrigen Zeit der Einspritzungen blieb die Temperatur meist normal, und stieg nur zuweilen Abends auf $37 \cdot 6-37 \cdot 8^{\circ}$. Locale Ver- 
änderungen am Ort der Kinspritzungen wurden nicht wahrgenommen, abgesehen von geringfügiger Anschwellung am Tag der Operation. Das börpergewicht nahm mit Schwankungen ab und betrug zum 26. April 56 Kilogramm, um 1.2 Kilogramm weniger, als im Anfang der Behandlung.

Der Verlauf der syphilitischen Erscheinungen war folgend:

13./II. Nach der 4. Einspritzung. Die Geschwüre an dem inneren Blatt des Präputiums und am Frenulum sind grösser geworden und haben das charakteristische Aussehen einer schankrösen Erosion angenommen. Die rechte Leistendrüse ist härter und grösser, es beginnt auch eine linke Leistendrüse anzuschwellen.

20./III. Nach 8 Einspritzungen. Harte Schwellung des unteren Theiles des Präputiums am Frenulum. Die Gesehwüre werden reiner. Es werden Umschläge nit $1 / 2 \%$ iger Lösung Arg. nitr, verordnet, und der Psoriasisausschlag wird mit 10\% iger Lösung von Chrysurubin in Traumaticin bestrichen.

30./III. Nach 11 Einspritzungen. Die Geschwüre sind beinahe vernarbt. Das Präputium ist hart infiltrirt. Die Drüsen sind unveräudert. Der Psoriarisausschlag ist beinahe verschwanden. An der rechten Seite und am Bauch einige blasse Roseolaflecken.

6./IV. Nach 14 Eiuspritzungen. Leichte Erhebung und Infiltration der rothen Flecken an den Seiten und am Bauch. Neue Flecken an den Vorderarmen. Der schuppige Ausschlag ist beinahe verschwunden.

13. IV. Nach 17 Einspritzungen. Der untere Theil des Präputium ist sehr hart. Am Bauch und an den Seiten zahlreiche Flecken syphilitischer Roseola, zum Theil in Papeln übergehend; zerstreute Papeln an der inneren Fläche der Oberextremitäten, am Rücken und an der behaarten Kopfhaut.

26.IV. Nach 25 Einspritzungen. Diffuse Verhärtung an Stelle der früheren Geschwüre. Vie rechte Leistendrüse ist halbweich, von den Axillardrüsen ist jederseits eine verluärtete, aber nicht grosse. Am ganzen Rumpf, an den Oberextremitäten, z. Th. an dem Gesäss und an den Oberschenkeln syphilitische Roseola, stellenweise Papeln. An der linken Tonsilla eine grosse schleimige Papel. Der schuppige Ausschlag ist verschwunden, unter Hinterlassung von Pigmentation. Es werden Quecksilbereinreibungen verordnet.

Am 7./VI., nach 34 Einreibungen zu 20 sind alle syphilitischen Erscheinungen verschwunden, die Drüsen und Verlı̈rtungen resorbirt.

Auch in diesem Fall haben also die Seruminjectionen keinen günstigen Einfluss auf den Krankheitsperlauf gehabt: die primären Geschwüre vergrösserten sich, indem ihr Aussehen mehr charalkteristisch wurde; die erste Eruption stellte sich zur üblichen Zeit ein - 5 Wochen nach Eintritt der Primäraffection - und war bis zur Verordnuns der Quecksilberbehandlung im Zunehmen begriffen. 
Die Behandlung der Syphilis mit Serum mercurial. Thiere. 237

III. S. F., 32jähriger Bauer, von brauner Haarfarbe, gut gebaut, Wuchs $173 \mathrm{Cm}$., Körpergewicht $63.6 \mathrm{Kg}$., erkrankte vor $1 \frac{1}{2}$ Monaten, war nicht behandelt worden. Aufgenommen am 12. Februar 1896 mit folgenden Erscheinungen: ein in Verheilung begriffenes hartes Schankergeschwür am inneren Blatt des Präputiums mit charaksteristischer Induration; rechts zwei harte grosse Leistendrüsen und vergrösserte, harte laterale Halsdrüsen, links eine grosse harte Cubitaldrüse. Am ganzen Rumpf, an den Ober- und Unterextremitäten sind reichliche lenticuläre und miliare Papeln mit centraler Schuppung, auch kleine pustulöse Papeln zerstreut; an der Glans penis und am Präputium ein miliares Syphilid. An der Stirn breite Papeln und Flecken. Harn eiweissfrei. Allgemeiner Gesundheitszustand befriedigend. Locale Umschläge aus Glycerin und Wasser. Seit dem 15. Februar 1896 wurden Einspritzungen von Quecksilberserum mit $0.5 \%$ Phenol vorgenommen, und davon bis zum 9. April 25 Injectionen mit Einverleibung von 280 Ccm. gemacht, wobei die 7., 8. und 9. Einspritzung zu je $20 \mathrm{Ccm}$. die übrigen, dreimal wöchentlich, zu je $10 \mathrm{Ccm}$. gemacht wurden.

Die Körpertemperatur war von der 2. Einspritzung ab bis zur 8. fieberhaft und stieg auf $38-38.7^{\circ}$; nach der 9 . bis zur 20 . blieb die Temperatur normal, obgleich sie Abends doch auf $37.5-37.8^{\circ}$ stieg; nach der 21., 24. und 25. stieg sie Abends bis 38.8. Die Einspritzungen waren meistens schmerzhaft und zuweilen von bedeutenden örtlichen Anschwellungen gefolgt, die nach 2 Tagen verschwanden. Nach der 4. Einspritzung wurde der Appetit schlechter und es stellten sich Schmerzen in der Hüfte und Diarrhöen ein, die 10 Tage lang anhielten. Der Harn war die ganze Zeit eiweissfrei. Der Allgemeinzustand war meistens befriedigend. Das Körpergewicht schwankte zwischen $6: 6$ und $65 \mathrm{Kg}$., und betrug am 9. April 65.6, hatte also um $2 \cdot 0$ zugenommen. Der Krankheitsverlanf war folgender:

21./II. Nach 4 Einspritzungen. Die Geschwüre am Glied granuliren, das Syphilid am Rumpf ist deutlicher und schuppt stellenweise ab, die Flecken an der Stirn sind schärfer ausgeprägt.

28./I. Nach 7 Einspritzungen. Einige Plaques des miliaren Syphilids am Bauch sind resorbirt, andere in Abschuppung begriffen; am Rücken bilden sich viele in pustulöse Papeln um; an den Unterextremitäten stellen sich neue Papeln ein, die alten schuppen ab.

4./III. Nach der 9. Einspritzung und bedeutender Temperatursteigerung (bis $39^{\circ}$ ). Das miliare Syphilid ist abgeblasst nnd wird am ganzen Körper und an den Extremitäten resorbirt. Die Axillardrüsen sind beiderseits schmerzhaft und hart. Die Geschwüre sind verheilt.

11./III. Nach 12 Einspritzungen. Der Schwund des Syphilids dauert fort. Die Glans penis ist frei von Papeln. Die Flecken an der Stirn bestehen fort. Die Leistendrüsen sind bedeutend weicher.

18./III. Nach 16 Einspritzungen. Viele Papeln am Bauch und an den Extremitäten werden von Neuem infiltrirt. 
26./III. Nach 19 Einspritzungen. Eine Drüse am liinn ist angeschwollen und hart; das Syphilid ist unverändert.

1./IV. Nach 22 Einspritzungen. Am Penis, Rumpf und an der Dorsalfläche der Oberextremitäten sind einige neue Papeln entstanden.

9./IV. Nach 25 Einspritzungen. Geringfügige teigige Verhärtung an Stelie des früheren Geschwürs; kaum wahrnehmbare Papeln an der Glans penis. Rechts eine, links zwei kleine harte Leistendrüsen; links eine harte, taubeneigrosse Cubitaldrüse; ausserdem sind links eine Occipitaldrüse, eine am $\mathrm{Obr}$ und eine unter dem Kinn geschwollen und verhärtet. Am Rumpf und an den Fxtremitäten ein stellenweise pigmentirtes miliares papulöses Syphilid, am Rücken und an den Oberextremitäten ein eben solcher reichlicher frischer Ausschlag, an den Seiten zahlreiche lenticuläre Papeln, zum Theil in Uebergang zu Pusteln. An der Stirn kaum bemerkbare Flecken, am Hals helle Roseola. Es wurden Quecksilbereinreibungen zu 2.0 verordnet.

Am 30./TV., nach 13 Einreibungen, sind alle Erscheinungen verschwunden. Nur Pigmentirung ist von dem Syphilid hinterblieben.

Auch hier wurde jeglicher Erfolg von den Serumeinspritzungen vermisst. Was Syphilid trat zwar für einige Zeit zurück, doch das geschah gerade nach bedeutender Temperatursteigerung (bis $39^{\circ}$ ), und als letztere verschwand, stellten sich neue Papeln ein, und auch die alten kamen wieder zum Vorschein, und zum Schluss der Behandlung war der Ausschlag noch reichlicher, als vor ihrem Beginn.

Der von Dr. Wreden veröffentlichte glänzende Erfolg des ron Dr. Dshergowski zubereiteten carbolisirten Quecksilberserums, das von im Institut für Experimentalmedicin mercurialisirten Pferden gewonnen wurde, wird durch diese drei Beobachtungen keinesfalls bestätigt. Im Gegentheil, der progressive Verlauf der syphilitischen Erscheinungen wurde durch die Einspritzungen in diesen drei Fällen nicht aufgehalten, und der Allgemeinzustand nicht günstig beeinflusst, was besonders aus der dritten Beobachtung ersichtlich ist.

IV. S. S., 23jähriger Bauer, blond, von mittelmässigem Körperbau, Wuchs $163 \mathrm{Cm}$., Körpergewicht $64.4 \mathrm{Kg}$.; er wurde am 24. Februar $18: 6$ mit Geschwüren an den Geschlechtstheilen aufgenommen. Seiner Angabe gemäss sind die ersten Geschwüre im November 1895 vier Tage post coitum am Präputium aufgetreten; darauf bildete sich linkerseits ein Bubo aus, der am 6. December aufgeschnitten wurde, später wurde er nur local behandelt. Die jetzigen Geschwüre will er seit Mitte Jänner 1896 bemerkt haben und behauptet, seit November den Coitus nicht ausgeäbt zu haben. Bei der Aufnahme fand sich ein granulirendes hartes Schankergeschwür am Frenulum, ungefähr $2 \mathrm{Cm}$. im Durchmesser; im 
Die Behandlung der Syphilis mit Serum mereurial. Thiere. 239

Sulcus retroglandularis links ausgeprägte Sclerose an Stelle eines verheilten Geschwürs, wodurch die Freilegung der Glans penis verhindert ist. In der linken Leistengegend der verheilte Schnitt des Bubos und zwei harte Drüsen; rechterseits ist die Schwellung der Drüsen geringfügig. Die linken hinteren lateralen Halsdrüsen sind vergrössert und verhärtet. An den Rumpfseiten einige blasse Roseolaflecken.

Am 24. Februar wurden zum ersten Mal $10 \mathrm{Ccm}$. Quecksilberserum ohne Phenol von dem Füllen Nr. III eingespritzt, welches wir durch Calomelinjectionen mercurialisirt hatten, $\left.{ }^{1}\right)$ und bis zum 22. April wurden dem Patienten im Ganzen 25 Einspritzungen gemacht mit Einführung von 290 Cem. Serum, da die 3., 4., 5. und 6. Einspritzung je $20 \mathrm{Ccm}$. eutbielten, die übrigen je 10. Das verheilende Geschwür wurde mit Umschlägen aus Glycerin und Wasser behandelt. Die Körpertemperatur war meistens normal mit Ausschluss der auf die 4., 5., 6., 8. und 12. Einspritzung folgenden Tage, wu sie Abends auf $38.1-38.5^{\circ} \mathrm{stieg}$, Morgens jedoch gegen $37^{\circ}$ betrug. Nach der 6. Einspritzung entstand an den Ober- and Unterextremitäten ein reichliches, fast diffuses, stark juckendes Erythen, welches später in Purpura sich umbildete und an den Beinen erst nach zwei Wochen verschwand. Nach der 8. Einspritzung traten noch heftige Schmerzen in den Muskeln der Unterschenkel hinzu, die nach fünf Tagen vergingen. Eiweiss war die ganze Zeit hindurch nicht im Harn aufgetreten.

Die syphilitischen Erscheinungen verliefen folgendermassen:

2./III. Nach 4 Einspritzungen. An den Rumpfseiten blasse Roseola, die Geschwüre sind fast verheilt.

Vom 8.-15./III., nach 9 Einspritzungen, ist die Roseola beinahe gänzlich geschwunden.

22./III. Nach 12 Einspritzungen. Die Roseola an den Seiten ist deutlicher. Die Cubitaldrüsen sind geschwollen und hart.

30./III. Nach 14 Einspritzungen. Die Roseola an den Seiten ist deutlicher und zahlreicher. Induration des Orificium externum urethrae. Opalescirende Plaques am oberen Zahnfleisch.

6./IV. Nach 17 Einspritzungen. Roseola an der inneren Fläche der Oberextremitäten und am Rücken; zwei Papeln an der Glans penis; Ausfallen der Haare am lopf und an den Augenbrauen.

13./IV. Nach 20 Einsuritzungen. Geringfügige Verhärtung an Stelle des früberen Geschwürs am Frenulum. Ausgeprägte Sclerose im Sulcus retroglandularis. Die Inguinal- und Cubitaldrüsen, ausserdem eine am Hinterhaupt links und eine hinten am Hals sind gescbwollen und hart. An der Glans penis und am Rand des Praeputium mehrere Papeln. Am

1) Sowobl bei diesem Patienten, als auch bei allen weiterfolgenden, wurden die Einspritzungen mit Quecksilberserum von den drei Füllen Nr. III, II und I gemacht, die wir durch Calomelinjectionen mercurialisirt hatten. 
Rumpf, an den Oberextremitäten und an der Stirn zahlreiche Roseolaflecken. Ausfallen der Haare. Plaques an der Unterlippe und Zunge.

22. IV. Nach 25 Einspritzungen. Induration an Stelle der früheren Geschwüre. Zwei Papeln an der Glans penis. Jederseits zwei kleine harte Leistendrüsen, die Cubitaldrüsen sind halbweich, die Axillar- und zwei Occipitaldrüsen links sind verhärtet. Am ganzen Rumpf, an den Oberextremitäten, zum Theil am Rücken und Kopf reichliche, bereits abblassende Roseola. Ausfallen der Haare am Kopf und an den Augenbrauen, auch der Wimpern. An den Nasenflügeln ein miliares kreisförmiges Syphilid. Am After Papeln. Am Zahnfleisch über den oberen Vorderzähnen zwei Papeln, an den Lippen und an der Wange gegenüber den Seitenzähnen je eine.

Es wurden Quecksilbereinreibungen zu $2 \cdot 0$ verordnet.

Am 7. Mai, nach 14 Einreibungen, wurde Patient aus der Klinik entlassen. Alle Erscheinungen, ausser dem Ausfallen der Kopfhaare und geringfügiger Verbärtung der Leistendrüsen, wasen verschwunden.

An diesem Patienten war der Verlauf der Syphilis durch 25 Einspritzungen von Quecksilberserum Nr. III durchaus nicht aufgehalten worden; die Erscheinungen an der Haut und an den Schleimhäuten hatten sich unaufhaltsam ausgebreitet. Anfänglich war die Roseola unter Einwirkung der gesteigerten Temperatur anscheinend zurückgetreten, aber später begann sie sich wieder zu verbreiten. Auf den Allgemeinzustand wirkte das Serum ebenfalls ungünstig, indem es Purpura, Muskelschmerzen und Fieber hervorrief. Das Körpergewicht fiel von 64.4 allmälig bis auf 62.4 , insbesondere während des Fiebers; später, zum Schluss der Behandlung, stieg es wieder bis $63 \cdot 6$ Kilo.

V. F. S., 26jähriger Soldat, von brauner Haarfarbe, $163 \mathrm{Cm}$. hoch, $58 \cdot 8 \mathrm{Kg}$. schwer, kam am 2. Mäßz 1896 zur Aufnahme. Fr hatle Geschwüre an den Geschlechtstheilen, die er am 20. Februar, 23 Tage post coitum bemerkt hat. Bei der exsten Untersuchung fand sich: am inneren Blatt des Präputiums links ausgesprochene Sclerose mit zwei fast confluirenden Schankererosionen, Zerfall im Centrum und geringfügiger Absonderung. Jederseits eine harte Leistendrüse; auch eine Drüse an der linken Lende ist verhärtet.

Am 6. März wurden zum ersten Mal $10 \mathrm{Ccm}$. Quecksilberserum Nr. III von dem nämlichen Füllen, wie in Beobachtung IV, eingespritzt; bis zum 6. April wurden 12 solcher Injectionen gemacht, also $120 \mathrm{Ccm}$. eingeführt. Die körpertemperatur war von der 3. Einspritzung ab die ganze Zeit hindurch fieberhaft, mit Ausnahme dreier Tage, als die Einspritzungen sistirt waren; sie stieg Abends bis auf $39 \cdot 2^{\circ}$, betrug nicht weniger als $38^{\circ}$, und Morgens $375-378^{\circ}$. Am 18. März, nach der 7 . Ein- 
Die Behandlung der Syphilis mit Serum mercurial. Thiere. 241

spritzung, bekam Patient ein reichliches, fast confluirendes Erythem an den Unterextremitäten, nach 2 Tagen auch an den Oberextremitäten, ausserdem Schmerzen im rechten Schultergelenk bei Armbewegungen und in den Unterkiefergelenken, so dass er den Mund nicht aufmachen konnte; Appetitverlust, Verstopfung, Albuminurie. Es wurde Natrum salicyl. zu 0.6 verordnet, vier Mal täglich, und nach 5 Tagen schwanden alle Erscheinungen. Während dieser Zeit waren die Seruminjectionen sistirt. Das Körpergewicht fiel während der Serumbehandlung von 58.8 auf $54 \mathrm{Kg}$. Der Verlauf der Syphilis war folgender:

16./II. Nach 6 Einspritzungen. Die Geschwüre sind verheilt, je eine Axillardrüse beiderseits geschwollen.

28./III. Nach 8 Einspritzungen. An der linken Rumpfseite und am Geschlechtsglied mehrere Papeln.

1./IV. Nach 10 Einspritzungen. Es sind Papeln an den Vorderarmen hinzugekommen, ausserdem Kopfschmerz, der zur Nacht zunimmt.

6./IV. Nach 12 Einspritzungen. Die Kopfschmerzen werden heftiger, besonders zur Nacht, und stören den Schlaf. Der Papelausschlag an den Seiten, am Rücken und Glied vermehrt sich; an der Brust und an den Oberextremitäten sind vereinzelte breite Papeln zerstreut. Ausgeprägte Sclerose an Stelle des früheren Geschwürs. Papeln an der Glans penis und am Präputium. Jederseits je zwei harte Leistendrüsen und je eine Axillardrüse. An der Zungenspitze eine schleimige Papel.

8./V. Wegen Zunahme der Kopfschmerzen, Versohlimmerung des Allgemeinbefindens und beträchtlicher Kräfteabnahme werden die Injectionen sistirt und Quecksilbereinreibungen zu 2.0 täglich verordnet.

Nach 4 Einreibungen vergingen die Kopfschmerzen und nach 24 auch alle anderen Erscheinungen.

Hier wurde jegliche Beeinflussung des Verlaufs der Syphilis durch das Serum vermisst; zugleich hatte die Serumbehandlung unangenehme Complicationen zur Folge, als Erythem, Gelenkaffectionen, Fieber, Appetitverlust, Albuminurie, schliesslich Abnahme des Körpergewichts um 4.8 Kilo.

VI. D. J., 26jähr. Soldat von brauner Haarfarbe, gut gebaut, $167 \mathrm{Cm}$. hoch, $68 \mathrm{Kg}$. schwer; aufgenommen am 2. März 1896 mit Geschwüren an den Geschlechtstheilen, die or am 24. Februar, 25 Tage post coitum, bemerkt haben will. Die Untersuchung erwies in sulco retroglandulare, in der Mittellinie, ein ungefähr $3 \mathrm{Cm}$. grosses hartes Schankergeschwür mit charakteristischer Induration; es reicht auf den Rand der Glans penis herüber. Ein eben solches und eben so grosses Geschwür im Winkel des Frenulums links. Jederseits zwei harte geschwollene Leistendrüsen; die Cubitaldrüsen sind erbsengross und weich. Am Kreuz drei Pusteln (Impetigo vulgaris); locale Behandlung derselben mit Umschlägen aus $1 / 2 \%$ iger Lösung Arg. nitr. und Unguent. diachyli. Am 2. März 1896 wurde die erste Einspritaung von Quecksilberserum Nr. III gemacht, welches in den zwei vorigen Beobachtungen benutzt wurde. Bis zum 
26. April bekam Patient im Ganzen 25 Einspritzungen mit $280 \mathrm{Ccm}$. Serum; die 4., 5. und 6. zu je 20 Ccm., die übrigen zu $10 \mathrm{Ccm}$. Die Körpertemperatur war fast die ganze Zeit hindurch, von der 2. Einspritzung ab, erhöht, indem sie zwischen $37 \cdot 2-37 \cdot 5^{0}$ Morgens und 38- $38.5^{\circ}$ Abends schwankte. Allgemeinzustand und Appetit waren befriedigend. Das Körpergewicht nahm mit Schwankungen ab und fiel zum Schluss der Beobachtung von $68^{\circ} 0$ auf $66^{\circ} 0 \mathrm{Kg}$.

Die syphilitischen Erscheinungen verliefen in folgender Weise:

11./III. Nach 5 Einspritzungen. Die Geschwüre werden rein und granuliren. Die Leistendrüsen sind im früheren Zustand. Von den Axillardrüsen sind jederseits zwei angeschwollen.

28./II. Nach 10 Einspritzungen. Die Geschwüre sind vernarbt und haben Indurationen hinterlassen. Der Rumpf marmorescirt.

6./IV. Nach 14 Einspritzungen. Blasse Roseola an den Seiten und Handtellern. Schleimige Papeln an beiden Tonsillen und beiden Lippen.

13./IV. Nach 17 Einspritzungen. Die Roseola breitet sich in Gestalt grosser Flecken auf den Bauch, Rücken und die Oberextremitäten aus und bildet sich an den Händen in Papeln um. Anschwellung der 0ccipitaldrüsen linkerseits. Schleimige Papeln an beiden Tonsillen und Lippen; örtliche Behandlung derselben mit 2\%iger Lösung von Arg. nitric.

26./IV. Nach 25 Einspritzungen. Geringfügige Sclerose an Stelle der früheren Geschwüre neben dem Frenulum. Von den Leistendrüsen ist jederseits eine halbweich, beide Cubitaldrüsen und zwei jederseits von den Axillardrüsen sind gross und hart, eine Occipitaldrüse linkerseits geschwollen. Reichliche Roseola am ganzen Rumpf, an den Oberextremitäten, am Gesäss und an den Händen in Gestalt grosser Flecken. Papeln an den Tonsillen und beiden Lippen.

Es werden Quecksilbereinreibungen zu 2.0 verordnet.

7./VI. Nach 36 Einreibungen. Alle Erscheinungen sind geschwunden.

Auch dieser Fall zeigt, dass der ïbliche Verlauf der Syphilis durch die Seruminjectionen nicht aufgehalten wurde. Die Erscheinungen schritten unaufhaltsam fort. Der Allgemeinzustand des Organismus verschlimmerte sich durch das beständige Fieber, was sich eben in Abnahme des Körpergewichts offenbarte.

VII. G. P., 26jähr. Soldat, von durkelbrauner Haarfärbung, mittelmässigem Körperbau, mager, $174 \mathrm{Cm}$. hoch, 69.6 Kg. schwer. Aufgenommen am 24. Mai 1896 mit einem Geschwür am Glied, welches von ihm am 20. Mai, 3 Wochen post coitum bemerkt wurde. Am 29. Mai fand sich in sulco retroglandulare rechts vom Frenulum ein gegen $3 \mathrm{Cm}$. grosses Geschwür mit schmutzig-grauem Centrum, erodirten Rändern und knorpeliger Induration am Hoden und am Rand. Rechts zwei kleine harte Leistendrüsen.

Am 6. Juni wurde die 1. Einspritzung Quecksilberserum von dem Füllen Nr. I gemacht, welches wir, wie auch das vorige, durch Calomel- 
injectionen mercurialisirt hatten. Patient bekam zum ersten Mal $10 \mathrm{Ccm}$. und bis zum 22. Juni 10 solche Einspritzungen, also im Ganzen $100 \mathrm{Ccm}$. Serum.

Die Körpertemperatur betrug vor den Einspritzungen gegen $36^{\circ}$; nach den ersten 4 Einspritzungen stieg sie ein wenig und betrug Abends $37^{\circ}$ und Morgens $36^{\circ} 5^{\circ}$. In der übrigen Beobachtungszeit schwankte die Temperatur um $365^{\circ}$. Im Harn kein Eiweiss. Das Körpergewicht fiel im Verlauf dieser Zeit mit geringfügigen Schwankungen von 59.6 auf $58.8 \mathrm{Kg}$.

Die syphilitischen Erscheinungen verliefen folgendermassen:

10./VI. Nach 3 Einspritzungen. Das Geschwür granulirt; an den Seiten schwacher Roseolaausschlag.

17./VI. Nach 7 Einspritzungen. Das Schankergeschwür ist in Vernarbung begriffen, die Roseola-Flecken an der Brust und an den Seiten nehmen zu, breiten sich auf den Rücken und die Oberextremitäten aus. Schwellung der Axillardrüsen.

22./VI. Nach 10 Einspritzungen. Die Roseola-Eruption dauert fort und nimmt den ganzen Rücken und die Oberextremitäten ein. Patient leidet an Kopfsehmerzen, die zum Abend zunehmen.

24./VI. Die Kopfschmerzen sind so heftig, dass sie wäbrend der ganzen Nacht den Schlaf verhindern; am Tag nehmen sie ab. Der Schanker ist fast verheilt; ringförmige Sclerose um den Rand herum von knorpeliger Beschaffenheit. Reohts drei harte Leistendrüsen; jederseits eine harte Axillardrüse. Am ganzen Rumpf und an den Extremitäten reichlicher Roseola-Ausschlag; erythematöse Angina. Die Seruminjectionen werden sistirt und an ihrer Stelle Quecksilbereinreibungen zu $2 \cdot 0$ verordnet. Nach 8 Einreibungen vergingen die Kopfschmerzen, und nach 32 verschwanden alle Erscheinungen.

Auch dieser Fall spricht nicht zu Gunsten der Seruminjectionen, da die Erscheinungen sich trotz derselben rasch entwickelten, und da solche heftige und bedrohliche Kopfschmerzen auftraten, dass es nöthig wurde, die Einspritzungen aufzugeben. Der Allgemeinzustand war durch das Serum dahin beeinflusst worden, dass die Körpertemperatur um einen Grad stieg; ubrigens kann diese Temperatursteigerung auch durch das Eruptionsfieber bedingt worden sein, da nach der dritten Einspritzung sich die ersten Roseolaflecken einstellten.

VIII. P. N., 19jähriger Kleinbürger, brünett, mager, $162 \mathrm{Cm}$. hoch, 51.2 Kilo sehwer, aufgenommen am 26. Juni 1896 mit einem Geschwür am Glied, welches von ihm Ende Mai, ungefähr 10 Tage post coitum. entdeckt worden war. Die Untersuchung ergab rechts am Penis ein hartes Schankergeschwür, gegen 3-4 Cm. im Durchmesser, auf indurirter Basis. Rechterseits zwei, linkerseits eine harte Leistendrüse. Harn ohne Eiweiss. Umschläge aus Glycerin und Wasser. 
Am 1. Juli wurden zum erstenmal $10 \mathrm{Ccm}$. Quecksilberserum Nr. III eingespritzt, und bis zum 10. August bekam Patient 20 Einspritzungen, enthaltend $200 \mathrm{Ccm}$. Serum.

Die Körpertemperatur blieb während der ganzen Beobachtungsdauer normal, mit Ausnahme zweier Tage nach der 4. und 10. Einspritzung, als die Temperatur am Abend auf $384^{\circ}$, beziehungsweise $37.8^{\circ}$ stieg. Nach der 3. Einspritzung stellte sich geringfügige Albuminurie ein, die nach 2 Tagen verschwand. Ferner traten nach der 5. Einspritzung Schmerzen in den Waden und Erythem im Gebiet der Sprunggelenke auf; am nächsten Tag gesellte sich dazu Schmerz in den Knien ohne objective Erscheinungen, Appetitmangel und allgemeines Schwächegefühl. Nach 5 Tagen verschwand das Erythem, doch die Schmerzen in den Knien kehrten von Zeit zu Zeit wieder, und nach der 13. Einspritzung stellten sich ausserdem Schmerzen im rechten Schultergelenk ohne bemerkbare locale Erscheinungen ein. Darauf schwanden diese Erscheinungen allmälig von selbst. Das Körpergewicht schwankte zwischen 50-51.4 Kilo und betrug zum Schluss der Beobachtung 51.2, ebensoviel wie im Beginn derselben.

Verlauf der syphilitischen Manifestationen :

6.jVII. Nach 3 Einspritzungen. Das Geschwür hat sich gereinigt, und granulirt. An den Rumpfseiten etliche blasse Roseolaflecken.

15./VII. Nach 6 Einspritzungen. Die Roseola hat zugenommen und sich auf den Rücken und die Oberextremitäten ausgedehnt. Der Schanker ist vernarbt. Die Drüsen sind etwas weicher.

22./VII. Nach 10 Finspritzungen. Induration an Stelle des Geschwürs. Roseola am ganzen Körper und an den Extremitäten.

31./VII. Nach 14 Einspritzungen. Zu den vorigen Erscheinungen sind noch kleine Papeln am Hodensack und Penis hinzugetreten.

10./VIII. Nach 20 Einspritzungen. An Stelle des früheren Geschwürs ausgeprägte Induration; an der unteren Fläche des Gliedes eine Papelgruppe; am Hodensack kleine Papeln in der Schuppungsperiode. Reichliche Roseola am ganzen Körper und an den Oberextremitäten. Opalescirende Plaques am rechten hinteren Gaumenbogen. Die Leistendrüsen sind halbweich.

Allgemeinzustand und Appetit befriedigend.

Die Einspritzungen werden sistirt, und darauf Quecksilbereinreibungen zu 2.0 verordnet. Nach 26 Einreibungen verschwanden alle Erscheinungen, und Patient wurde entlassen.

Durch diesen Fall wird wieder die Machtlosigkeit des Quecksilberserums gegenüber dem progressiven Verlauf der ersten syphilitischen Eruption bestätigt. Ausserdem bekam dieser Patient nach den Einspritzungen Erythem an den Beinen, rheumatoide Gelenkschmerzen und Albuminurie.

IX. M. M., 40jähriger Bauer, blond, von mittelmässiger Statur und Ernährung, $150 \mathrm{Cm}$. hoch, 57·2 Kilo schwer, aufgenommen am 2. Juli 
1896 mit Geschwüren an den Geschlechtstheilen, die von ihm am 25. Mai, 3 Wochen post coitum entdeckt wurden; er war local mit Jodoform behandelt worden.

Die Untersuchung erwies in Sulco retroglandulare rechts eine, links zwei Schankererosionen auf indurirter Basis; rechts eine grosse und harte Leistendrüse, eine andere etwas kleiner und weicher, links eine halbweiche. An der linken Seite blasse Roseolaflecken. Im Harn Eiweissspuren, aber kein Quecksilber. Am 8. Juli wurde die erste Einspritzung Quecksilberserum Nr. II in der Quantität von $10 \mathrm{Ccm}$. gemacht, und bis zum 26. August bekam Patient 26 solche Einspritzungen, enthaltend $260 \mathrm{Ccm}$. Serum. Die Temperatur schwankte während der ganzen Beobachtungsdauer in normalen Grenzen, mit Ausnahme eines Tages nach der 5. Einspritzung, als sie Abends auf $37 \cdot 9^{\circ}$ stieg und wo zugleich Diarrhoe mit Leibschmerzen auftrat, die nach 2 Tagen verging; die Diarrhoe wiederholte sich für einen Tag nach der 18. Einspritzung. Im Allgemeinen vertrug Patient die Seruminjectionen ganz gut, und sein Appetit and Allgemeinbefinden verschlimmerten sich nicht. Das Körpergewicht fiel allmälig, indem es zwischen 57.8-57.0 schwankte und zum Schluss der Beobachtung 56.8 erreichte.

Die syphilitischen Erscheinungen verliefen folgendermassen:

13./VII. Nach 4 Einspritzungen. Die Roseola an den Seiten nimmt zu und breitet sich auf den Bauch aus; die Geschwüre am Glied granuliren. Die Axillardrüsen sind geschwollen und schmerzhaft.

20./VII. Nach 8 Einspritzungen. Die Geschwüre sivd verheilt und haben Sclerose hinterlassen. Roseolaflecken an Brust und Bauch in gering. fügiger Anzahl und blass. Papeln in der rechten Leistengegend. Die Drüsen sind etwas weicher. Quecksilberspuren im Harn. Es werden heisse locale Bäder wegen der Sclerose verordnet.

29./VII. Nach 12 Einspritzungen. Die Drüsen und Sclerosen sind weicher geworden. Schwach ausgeprägte Roseola an Brast und Bauch. 5./VIII. Nach 16 Einspritzungen. Die Papeln in der rechten Leistengegend gelangen zur Resorption. Roseola kaum zu bemerken.

14./VIII. Nach 20 Einspritzungen. Geringfügige Induration an Stelle der früheren Geschwüre. Die Leistendrüsen sind beinahe im normalen Zustand. Zwei Cubitaldrüsen sind hart. Die Papeln an der rechten Leistengegend sind beinahe resorbirt. Roseola am Bauch kaum wahrnehmbar.

26./VIII. Nach 26 Einspritzungen. An Stelle der früheren Geschwüre Sclerosen. Links eine, rechts zwei halbweiche Leistendrüsen. Cubitaldrüsen erbsengross, halbweich; Axillardrüsen taubeneigross, hart; präauriculare exbsengross. Die Papeln an der rechten Leistengegend sind resorbirt. Schwach angedeutete Roseola an der linken Seite. Keine weiteren Erscheinungen. Im Harn deutliche Quecksilberspuren. Patient wollte sich keiner anderen Behandlungsweise unterziehen und wurde entlassen. 
In diesem Fall wurden die Seruminjectionen gut vertrager und führten zu keinen Complicationen. Die syphilitischen Manifestationen verschwanden anscheinend sehr langsam und allmälig, doch jedenfalls war das macu]öse Syphilid, bei welchem die Einspritzungen angefangen wurden, trotz der langandauernden Behandlung (38 Tage) noch vorhanden.

X. N. D., 20jähr. Bauer, blond, gut gebaut, $159 \mathrm{Cm}$. hoch, $60^{4} 4 \mathrm{Kg}$. schwer, aufgenommen am 29. August 1896 mit subacuter Urethritis und einem Geschwür am Glied. Pat. kann den Anfang des Geschwüres nicht angeben; er coitirte am 15. August, und zwei Tage danach stellte sich Urethritis ein. Bei der Aufnahme fand sich in Sulco retroglandulare rechts ein hartes Schankergeschwür mit beträchtlichem Zerfall auf knorpeliger Basis. Die äussere Canalöffnung ist geschwollen, hart und sondert schleimig-eitrige Flüssigkeit ab. Jederseits eine harte Leistendrüse. Die Cubitaldrüsen sind klein und weich. Im Harn Eiweissspuren, kein Quecksilber. Es werden Injectionen der Urethra, ferner Umschläge aus Glycerin und Wasser anf das Geschwür und innerlich $0 \cdot 6$. Natri salicyl. dreimal täglich verordnet. Am 12. September wurden zum erstenmal $10 \mathrm{Ccm}$. Quecksilberserum Nr. III eingespritzt, und bis zum. 17. October 15 solche Einspritzungen mit Einführung von $150 \mathrm{Ccm}$. genacht. Die Körpertemperatur war die ganze Zeit normal. Nach der 6. Einspritzung trat juckendes Erythem an den Unterschenkeln und Vorderarmen auf, welches wieder nach 3 Tagen verschwand. Die Einspritzungen wurden im Allgemeinen gut vertragen. Das Körpergewicht veränderte sich in unbedeutender Weise und war am Schluss der Behandlung fast ebenso gross, wie im Beginn derselben (60.0 Kilo).

Verlauf der syphilitischen Manifestationen:

15./IX. Nach 3 Einspritzungen. An Bauch und Brust etliche blasse Roseolaflecken.

24./IX. Nach 6 Einspritzungen. Das Geschwür granulirt. Leistendrüsen verhärtet. Das maculöse Syphilid nimmt zu und breitet sich auf die innere Fläche der Vorderarme ans. Am Präputium zwei Papeln.

2./X. Nach 9 Einspritzungen. Der Schanker ist vernarbt, mit Hinterlassung einer Sclerose. Reichliche Roseola am ganzen Rumpf und an den Extremitäten. Quecksilberspuren im Harn.

10./X. Nach 12 Einspritzungen. Roseola am Rücken kaum wahrnehmbar, an der Brust und an den Seiten abgeblasst. Drüsen und Sclerose hart. Papeln am After.

17./X. Nach 15 Einspritzungen. Ausgeprägte Sclerose an Stelle des Geschwürs. Jederseits zwei harte Leisten- und eine harte Axillardrüse. Die Roseola am Rumpf und an den Extremitäten ist blasser. An der Stirn und linken Wange miliares kreisförmiges Syphilid. Eine breite Papel am After. Im Harn Quecksilberspuren. 
Die Einspritzungen werden aufgegeben, und Quecksilbereinreibungen $z u 2 \cdot 0$ verordnet. Nach 20 Einreibungen sind alle Erscheinungen verschwunden, mit Ausnahme geringfügiger Verhärtnng an Stelle der Sclerose.

In diesem Fall schienen sich die syphilitischen Erscheinungen etwas langsamer zu entwickeln als gewöhnlich. Die Roseola wurde bald blasser, bald wieder intensiver, und dann stellten sich Papeln ein. Patient vertrug das Serum gut, indem letzteres nur auf kurze Zeit unbedeutendes Erythem hervorrief.

XI. A. S., 27jähr. Bauer, von brauner Haarfarbe, gut gebaut, $170 \mathrm{Cm}$. hoch, 76.4 Kilo sehwer, aufgenommen am 23. September 1896. Patient hatte angeblich im März 1896 den letzten Coitus, und zwar mit einer Prostituirten, will keinen Schanker gehabt haben und überhaupt bis zum Juni gesund gewesen sein; da habe er heftige Kopfschmerzen und einen Ausschlag am Körper und Kopf bekommen. Er war nicht behandelt worden.

Die Untersuchung ergab einen Ausschlag grosser pustulöser Papeln am ganzen Rumpf, Kopf, an den Ober- und Unterextremitäten, insbesondere am Rücken (Patient ist Lastträger). Der Ausschlag ist meistens mit braunen Krusten bedeckt. In den Achselhöhlen, Leistengegenden und am After trockene lenticuläre und nässende Papeln; an der Haut des Gliedes breite Condylome; an den Oberextremitäten und am Rücken zahlreiche Pigmentflecken - Reste früherer Papeln. Die Leistendrüsen, lateralen Halsdrüsen und eine Cubitaldrüse rechts sind etwas geschwollen. Keine weiteren Erscheinungen. Im Harn ist weder Eiweiss, noch Quecksilber nachweisbar. Am 27. September bekam Patient die erste Einspritzung Quecksilberserum Nr. II in der Quantität von $10 \mathrm{Ccm}$. und bis zum 2. November in 15 Einspritzungen $150 \mathrm{Ccm}$. Die Injectionen waren meistens schmerzhaft und nach manchen stellten sich beträchtliche Anschwellungen und Röthung der Haut ein, die sich weit über die Einspritzungsstelle ausbreiteten. Die Körpertemperatur war von der 4. bis zur 10. Einspritzung im Verlauf von 20 Tagen fieberhaft und stieg sogar (nach der 6. Einspritzung) auf $39 \cdot 6^{\circ}$; dabei stellte sich auch Albuminurie ein. Meistens stieg die Temperatur am Tage der Einspritzung auf $38-3,5^{\circ}$ and wurde dann wieder nach zwei Tagen normal. Die anderen 8 Einspritzungen hatten keine Temperatursteigerung zur Folge. Der Verlauf des Syphilids war folgend:

2./X. Nach 3 Einspritzungen. Die Axillardrüsen sind geschwollen und etwas schmerzhaft. Die Papeln am Rumpf werden blasser und einige Krusten beginnen abzufallen.

10./X. Nach 6 Einspritzungen (Fieber bis 39.5\%). Die Papeln werden rasch resorbirt und hinterlassen Pigmentirung. Fast alle Krusten sind abgefallen. 
23./X. Naeh 10 Einspritzungen. Fast alle Papeln sind resorbirt, nur wenige sind nachgeblieben - an den Achselböblen, am Kopf und an der Leistengegend. Rechterseits eine vergrösserte harte Leistendrüse, links eine kleinere, und auch eine eben solche Axillardrüse. Keine Albuminurie. Geringfügige Quecksilberspuren im Harn.

31./X. Nach 14 Einspritzungen. Alle Papeln sind resorbirt, mit Ausnahme von $2-3$, die am Kopf sitzen und noch infltrirt sind. An den Händen breite Roseolaflecken.

2./XI. Nach 15 Einspritzungen. Quecksilberspuren im Harı. Die Roseola an den Händen wird deutlicher, nimmt zu und breitet sich auf die Vorderarme aus. Die Inguinal- und Axillardrüsen sind klein und hart. Die Schleimbäute sind unverändert.

6./XI. Grosse Roseolaflecken an Brust, Seiten, Rücken und Oberextremitäten. Verordnung von Quecksilbereinreibungen zu 2*0. Nach 24 Einreibungen sind alle Erscheinungen verschwunden.

Dieser Fall ist besonders beweiskräftig bezüglich der günstigen Beeinflussung syphilitischer Erscheinungen durch Temperatursteigerung. So lange als die Einspritzungen bedeutende Temperatursteigerung bewirkten, wurde das Syphilid ziemlich rasch resorbirt, und wenn Patient entlassen worden wäre, bevor die Roseola auftrat, so hätte man leicht in einen Irrthum verfallen und $\mathrm{zu}$ dem fehlerhaften Schluss gelangen können, dass die Serumeinspritzungen Einfluss auf den Schwund des syphilitischen Ausschlags haben; doch das Recidiv in Gestalt reichlicher Roseola bei fortdauernder Behandlung mit Serumeinspritzungen, aber bei normaler Temperatur, erweist deutlich den Einfluss der Temperatursteigerung auf das Verschwinden der sichtbaren Krankheitserscheinungen. Das Körpergewicht begann nach dem Fieber abzunehmen und betrug zum Schluss der Beobachtung 74.8 Kilo - um 1.6 Kilo weniger, als anfänglich.

Da wir also in der condylomatösen Periode der Syphilis negative Ergebnisse bei Behandlung mit Seruminjectionen erhielten, während Dr. Wrede $n$ an gummösen Kranken günstige Resultate mit Quecksilberserum erreichte, so stellten wir, wie bereits oben erwähnt wurde, zur Probe fünf Beobachtungen in der gummösen Periode der Syphilis an.

XII. G. A., 30jähr. Kleinbürger, blond, $167 \mathrm{Cm}$. hoch, 58.8 Kilo schwer, von mittelmässigem Körperbau, aufgenommen am 24. Juli 1896 mit Geschwüren am Körper. Seiner Angabe nach ist or vor 7 Jahren erkrankt; 
er machte damals 30 Einreibungen und blieb dann bis Februar 1895 ohne Behandlung; als sich später Geschwüre am Iinken Untersehenkel, Vorderarm und am linken Handteller einstellten, wurde er local behandelt und nahm Jodkali ein. Im November 1895 und Februar 1896 befand er sich wegen des nämlichen Beingeschwürs im Alexanderhospital und wurde nur mit Mercurialpflaster behandelt. Im April 1896 bildeten sich Geschwüre am linken Vorderarm und rechten Gesäss. Bei der Aufnahme bot er folgende Erscheinungen dar: An Stelle des Primärgeschwürs am Glied eine $5 \mathrm{Cm}$. grosse, an ihrer Peripherie pigmentirte Narbe. Am linken Vorderarm und am linken Handteller mehrere zackige Narben nach tiefem impetiginösem Syphilid; zwei eben solche Narben am rechten Oberschenkel. Oben an der rechten Hinterbacke ein tiefes, $7 \mathrm{Cm}$. grosses Geschwür mit scharf umschriebenem Rand und gummösem Zerfall im Centrum; daneben ein eben solches etwas kleineres, bereits granulirendes Geschwür, an dessen Rand kleine zerfallene Knötchen zerstreut sind. Am linken Unterschenkel, nach aussen vom Knie ein gegen $4 \mathrm{Cm}$. grosses oberflächliches Geschwür von unregelmässiger Gestalt; im Centrum granulirt dasselbe, seine Ränder sind untergraben, und an ihnen sitzen zahlreiche kleine gummöse Geschwüre. Am unteren Drittel des linken Unterschenkels befindet sich an der äusseren Seite noch ein ungefähr $6 \mathrm{Cm}$. grosses Geschwür mit schwieligem Rand; dasselbe ist ebenfalls von unregelmässiger Gestalt und mit dunklen Granulationen bedeckt. Im Harn weder Eiweiss, noch Quecksilber. Localbehandlung mit Borsalbe.

Am 3. August wurden zum ersten Mal $10 \mathrm{Ccm}$. Quecksilberserum Nr. I eingespritzt, und bis zum 28. August im Ganzen $130 \mathrm{Ccm}$. in 13 Injectionen; länger wollte Patient nicht in der Klinik bleiben. Er vertrug die Einspritzungen schlecht, sie waren meistens schmerzhaft und hinterliessen zuweilen unbedeutende Anschwellungen. Nach der 4. Einspritzung traten im Harn Eiweissspuren auf, ausserdem abendliche Temperatursteigerung bis $38^{\circ} 4^{\circ}$. Nach der 5. stieg die Temperatur auf $37 \cdot 7^{\circ}$; die übrige Zeit blieb sie normal. Nach der 5. Einspritzung bekam Patient ein juckendes Erythem an den Cnterschenkeln, Schmerzen in der Hüfte und am rechten Knie und Eiweiss im Harn; nach Verabreichung von 0.6 Natr. salicyl. zwei Mal täglich vergingen alle diese Erscheinungen in drei Tagen. Nach der 8. Einspritzung klagte Patient über Muskelschmerzen im linken Bein, durch welche das Gehen erschwert wurde; sie vergingen nach zwei Tagen. Der Allgemeinzustand und Appetit waren die ganze Zeit verbältnissmässig gut. Die syphilitischen Erscheinungen verliefen in folgender Weise:

7./VIII. Nach 3 Einspritzungen. Das Geschwür an der Hinterbacke beginnt am Rande zu vernarben, dasjenige am Knie hat sich im Centrum gereinigt und granulirt; die herumliegenden kleinen Geschwüre sind mit Höllenstein gebeizt worden. Das Geschwür am Unterschenkel vernarbt an den Rändern; die Granulationen an seinem Boden sind hellroth. Die Axillardrüsen sind angeschwollen und schmerzhaft. 
16./VIII. Nach 6 Einspritzungen. Das Geschwür am Knie ist kleiner geworden, vernarbt an den Rändern, sein Boden hat sich gereinigt, die kleinen umliegenden Geschwüre sind nicht so tief. Das Geschwür am Gesäss neben dem Kreuzbein ist vernarbt, das andere grössere ebenfalls in Vernarbung begriffen. Das Geschwür am Unterschenkel vernarbt langsam am Rand.

21./VIII. Nach 9 Einspritzungen. Beide Geschwüre am Gesäss sind verheilt, und diejenigen am Unterschenkel kleiner geworden. Im Harn Quecksilberspuren.

28./VIII. Nach 13 Einspritzungen. Am Gesäss hat sich an einem der verheilten Geschwüre ein neues Knötchen gebildet, das obere Geschwür am Knie vernarbt; um dasselbe herum sind zahlreiche neue kleine in Zerfall begriffene Knötchen. Das untere Geschwür am Unterschenkel ist mit Granulationen bedeckt, vernarbt an den Rändern, und hat sich um die Hälfte verringert. Patient ging nicht darauf ein sich einer weiteren Behandlung mit Quecksilbereinreibungen zu unterziehen und wurde entlassen.

In dieser Beobachtung haben die Geschwüre unter Einwirkung der Seruminjectionen ein besseres Aussehen bekommen, einige sind sogar verheilt, aber zum Schluss der Behandlung traten von Neuem gummöse Knötchen auf. Die Einspritzungen waren schmerzhaft und riefen Erythem, Gelenkschmerzen, Fieber und Eiweiss im Harn hervor. Das Körpergewicht stieg während der Beobachtung von 58.8 auf $59 \cdot 2$ Kilo.

XIII. L. D., 20jähar. Kleinbürger, brünett, mager, schwachen Körperbaues, $171 \mathrm{Cm}$. hoch, 50.8 Kg. schwer, aufgenommen am 3. September 1896 .

Er erkrankte im Jahre 1891, wurde nur local behandelt, hat keine allgemeine Cur durchgemacht. Im Juni 1893 bekam er Schnupfen mit eitriger und blutiger Absonderung, mit üblem Geruch und Verlust der Geruchsfähigkeit; ein Jahr darauf begann er sich behandeln zu lassen, aber ohne Erfolg. Im Jahre 1895 machte er zum ersten Mal eine Quecksilbercur durch, bekam 45 Einreibungen und Jodkali; danach verging der Schnupfen beinahe vollständig und die Geruchsfähigkeit kehrte wieder. Im Januar 1896 stellte sich von Neuem Schnupfen mit Krustenbildung, üblem Geruch, und Schwellung der linken Jochgegend ein; aus der Nase entleerten sich fünf Knochenstückehen. Bei der Aufnahme ergab die Untersuchung Folgendes: In der linken Jochbeingegend an der Nasenwangenfalte ein gegen $5 \mathrm{Cm}$. grosses, tiefes ovales Geschwür mit scharf abstehenden Rändern, mit schmutzig-granem Belag und Eiter bedeckt, mit entzündlicher Röthung rund herum. Beide Nasenknochen sind geschwollen und schmerzhaft. An der Schleimhaut am oberen inneren Vorderzahn die Oeffnung einer $5 \mathrm{Cm}$. langen Fistel. An der Grenze des harten und weichen Gaumens eine eingezogene Narbe. Der Knorpeltheil der Nasenzwischenwand ist vernichtet, die Basis des Nasenwurzelknochens 
auf grosser Strecke entblösst; die Nasenschleimhaut ist hyperämisch, sondert Eiter und dunkle Krusten ab; Kakosmia objectiva. Im Harn Eiweiss und Quecksilber, letzteres in grosser Menge. Es werden Gasbäder bis $60^{\circ}$ jeden zweiten Tag, Ausspülung der Nase mit 1\% Borsäurelösung und Carbolgazeverband der Geschwüre verordnet. Nach zwei Wochen enthält der Harn nur noch Spuren von Eiweiss und Quecksilber, die Geschwüre sind reiner, die übrigen Erscheinungen unverändert.

Am 17. September wurden zum ersten Mal $10 \mathrm{Cem}$. Quecksilberserum Nr. 1 eingespritzt, und bis zum 26. October im Ganzen $150 \mathrm{Ccm}$. in 15 Injectionen. Die Körpertemperatur war während der ganzen Behandlungszeit fieberhaft, sie stieg Abends über 37.5 bis $37.9-38^{\circ}$, und nach der 3., 4. und 5. Einspritzung sogar auf $38.5-39^{\circ}$. Nach der 3. Einspritzung schwollen die Axillardrüsen an; mehrere Einspritzungen hatten Röthung, Anschwellung und Schmerzhaftigkeit am Ort der Injection zur Folge. Nach der 5. Einspritzung trat im Gebiet des Sprunggelenks an beiden Füssen ein juckendes Erythem auf, das nach 4 Tagen verschwand. Das Körpergewicht nahm ein wenig ab und fiel zum Schluss der Beobachtung auf $49 \cdot 6 \mathrm{Kg}$. Die syphilitischen Manifestationen veränderten sich folgendermassen:

23./IX. Nach 4 Einspritzungen. Das Geschwür an der Wange hat sich gereinigt, die Fistel am Oberkiefer ist bedeutend kürzer geworden.

8./X. Nach 8 Einspritzungen. Das Geschwür an der Wange granulirt and vermindert sich, an seiner Umgebung entstehen nene Knötchen, die sich mit Krusten bedecken; die Entblössung des Nasenwurzelknochens besteht unverändert, der Schnupfen hat abgenommen.

17./X. Nach 12 Einspritzungen. Das Geschwür an der Wange beginnt nach Ausbeizung mit Höllenstein zu vernarben; an seiner Peripherie bilden sich zwei neue kleine Geschwüre. Im Harn Spuren vov Eiweiss.

26./X. Nach 15 Einspritzungen. Das Geschwür an der Wange ist beinahe verheilt, aber an seiner Peripherie sitzen einige neue zerfallende Knötchen. Die Schwellung der Nasenknochen ist die nämliche, die Krustenabsonderung aus der Nase vermindert. Der Harn enthält weniger Eiweiss und schwache Spuren von Quecksilber. Es worden Quecksillerfrictionen zu $2 \cdot 0$ und Jodkali zu $2 \cdot 0$ täglich verordnet. Nach 32 Frictionen ist das Gumma an der Wange gründlich vernarbt, die Knötchen in seiner Umgebung sind resorbirt, der abgestorbene Knochen aus der Nasenzwischenwand ist stückweise ausgestossen, und die Schleimhaut der Nase beinahe von normalem Aussehen.

Gummöse Geschwüre können sich bekanntlich bei Beobachtung von Sauberkeit allmälig ron selbst schliessen, und bei localer Beizung noch rascher; in Folge dessen darf in diesem Fall der Behandlungseffect nicht den Serumeinspritzungen allein zugeschrieben werden, um so mehr, als während der Behand- 
lung neve Knötchen entstanden und die Periostitis der Nasenknochen unverändert blieb. Ueberhaupt war das Ergebniss der Einspritzungen negativ.

XIV. S. A., 28jähr. Kleinbürger, von brauner Haarfarbe, schwachem Körperbau, mager, $168 \mathrm{Cm}$. hoch, $47 \cdot 6 \mathrm{Kg}$. schwer, aufgenommen am 3. September 1896. Er war im April 1890, drei Wochen post coitum, erkrankt. Die erste Eruption war ein maculöses Syphilid, welches nach drei Injectionen yon Hydrarg. salicyl. yerschwand. Darauf blieb Patient einen Monat lang ohne Behandlung. Es entwickelte sich Adenitis in der Leistengegend, die von selbst aufbrach, und ein Geschwür an der hinteren Rachenwand; 12 Frictionen und Localbehandlung. Die Erscheinungen verschwanden und der Allgemeinzustand verbesserte sich, aber seitdem bildeten sich fast fortwährend Geschwüre im Rachen. Gleichzeitig mit der ersten Eruption stellte sich eitriger Schnupfen ein, der nach sechs Monaten mit Ausstossen eines Knochensplitters aus der Nase endete. Im 9. Monat der Krankheit, 1891, litt Patient an Knochenschmerzen und Myositis bicipitis brachii; sie vergingen nach Jodkaligebranch. Im Jahre 1892 hatte er Geschwüre im Rachen und Papeln am After; 11 Frictionen und Jodkali zwei Monate lang im Kalinkinspital; die Geschwüre waren noch beim Verlassen des Spitals vorhanden. 1893 Geschwüre an der hinteren Rachenwand, Katarrh der Tuba Eustachii, eitrige Entzündung des Mittelohres mit Durchbruch des Trommelfells; ein ganzes Jahr hindurch mit Unterbrechungen Quecksilberfrictionen und Jodkali. 1894 lag Patient in der Klinik mit Papeln an der Zange und Geschwüren an der hinteren Rachenwand; Behandlung mit 17 Einspritzungen Hydrarg. salicyl. und Jodkali. 1895 ulceröse Affection der Uvula mit Zerstörung derselben und Geschwüre im Nasenrachenraum; Localbehandlung und Jodkali innerlich. Diese Geschwüre wiederholten sich noch mehrere Male im Venlauf der Jahre 1895 und 1896; im Jahre 1895 warde noch ein Knochenstückchen aus der Nase ausgestossen.

Die gegenwärtigen Erscheinungen haben sich ungefähr vor einem Monat ausgebildet. Patient ist von schwächlicher Statur und Ernährung, ein Fettpolster fehlt ihm fast ganz. Am Hals rechts und an der inneren Flä,che des rechten Oberschenkels alte entfärbte Narben mit gezacktem Rand. Recbts kleine harte Leistendrüsen; beide Submaxillardrüsen sind stark vergrössert, hart und schmerzhaft. Die ganze hintere Rachenwand und beide Gaumenbögen sind in ein confluirendes Geschwür mit scharf abstehenden Rändern verwandelt, mit Detritus und Eiter belegt. Die Uvula ist vernichtet. An der Grenze des harten und weichen Gaumens längs der Raphe befindet sich eine an ihren Rändern mit Zerfall bedeckte spaltformige Oeffuung, die in den hinteren Theil der Nasenböhle führt; die Knochen sind nicht entblösst. Patient ist sehr schwach; sein Appetit ist gut, aber das Schlucken äusserst sohmerzhaft. Im Harn sind Spuren von Eiweiss und deutliche Quecksilberreaction. Es werden Gasbäder bis $60^{\circ}$, Ausspülung der Nase mit $1 \%$ Carbolsäurelösung und Beizung der 
Die Behandlung der Syphilis mit Serum mercurial. Thiere. 253

Geschwüre mit 20\% iger Lapislösung verordnet. Nach 8 Bädern haben sich die Geschwüre am Rachen beinahe geschlossen und die Ränder der Spalte. am weichen Gaumen gereinigt, aber an der hinteren Rachenwand in der Höhe der Epiglottis hat sich ein neues erbsengrosses Geschwür gebildet.

Am 17. September wurden zum ersten Mal $10 \mathrm{Ccm}$. Quecksilberserum Nr. II eingespritzt, und bis zum 6. October im ganzen $60 \mathrm{Ccm}$. in 6 Injectionen eingeführt. Die Körpertemperatur war während der ganzen Beobachtungsdaner fieberhaft - bis $38 \cdot 5^{\circ}$ Abends und $37 \cdot 2-37 \cdot 5^{0}$. Morgens. Nach der 4. und 5. Einspritzung stieg die abendliche Temperatur auf $39-39 \cdot 2^{\circ}$, und am Ort der Injectionen war Anschwellung und. Schmerz vorhanden. Drei Tage nach der 4. Einspritzung trat an beiden Sprunggelenken juckendes Erythem auf, das nach 5 Tagen verschwand. Das Körpergewicht fiel allmälig und hatte zum Schluss der Beobachtung nm $20 \mathrm{Kg}$. abgenommen. Die syphilitischen Erscheinungen verliefen in folgender Weise:

21./IX. Nach 3 Einspritzungen. Die Vernarbung der Geschwüre an. der hinteren Rachenwand schreitet fort; das neue Geschwür verbleibt im. nämlichen Zustand; oben am linken Gaumenbogen hat sich eine neue Ulceration eingestellt.

6. X. Nach 6 Einspritzungen. Die fast zugewachsene Oeffnung am. weichen Gaumen ist von Neuem ulcerirt und grösser geworden; die Geschwüre an den Gaumenbögen und der hinteren Rachenwand beginnen wieder zu zerfallen und sich auszubreiten; das Schlucken ist wieder. schmerzhaft, der Appetit nimmt ab, der Schlaf ist gestört.

In Anbetracht dieser Anzeichen offenbarer Verschlimmerung wurden die Serumeinspritzungen aufgegeben, und gemischte Quecksilber-Jodbehandlung vorgenommen; unter dem Einfluss. letzterer verschwand das Fieber; die Geschwüre am Rachen vernarbten, Appetit und Schlaf besserten sich, und die Genesung schritt rasch vorwärts. Also auch dieser Fall spricht. nicht zu Gunsten der Serumbehandlung, indem die syphilitischen Erscheinungen dabei wieder zunahmen, und indem die Einspritzungen Fieber und Erythem bewirkten.

XV. K. J., 16jähriger Bauer, blond, kräftig gebaut, $162 \mathrm{Cm}$. hoch, 60 Kilogramm schwer, aufgenommen am 1. October 1896. Seiner Angabe gemäss war er bis zu seinem 8. Jahr gesund; dann erkrankte er an der Kehle und wurde heiser - damals litten Viele im Dorf an der Kehle. Ein Jahr später bildeten sich Geschwüre an den Knien, die an einer Stelle verheilten und an einer anderen wiederkamen.

Bei der Aufnahme wurde gefunden: Patient ist von kräftiger Statur und Ernährung, sein Knochensystem ist gut entwickelt, es sind keine Degenerationszeichen vorhandea. Am unteren Drittel des rechten Oberschenkels sitzt eine Gruppe Knötchen, die einen handtellergrossen. Raum einnehmen, zum Theil ulcerirt, zum Theil vernarbt sind. Die- 
Narben sind unregelmässiger Gestalt, an der Peripherie pigmentirt und im Centrum entfärbt; sie nehmen mehr die Mitte der Gruppe ein, während am Rand neue oder frische Knötchen sitzen. Am rechten Knie von aussen ist eine entfärbte, gezackte, ungefähr $5 \mathrm{Cm}$. grosse Narbe, die von dem vor 8 Jabren vorhandenen Geschwür stammt. Drei eben solche vereinzelte Narben sitzen neben dem linken Knie (zwei am Ober-, eine am Unterschenkel). Eine zum Theil ulcerirte Gruppe syphilikischer Knötchen von der Grösse eines halben Handtellers befindet sich am Unterschenkel unter dem linken Knie; eine eben solche etwas kleinere Gruppe an der inneren Fläche des unteren Drittels des linken Vorderarms; oberhalb dieser Gruppe liegen mehrere ganz entfärbte gezackte Narben von früheren Gesehwüren. Am rechten Ellbogen ist eine Gruppe trockener Knötchen, vermischt mit Narben von vorjährigen Geschwüren; am linken Ellbogen ein charakteristisches gummöses Geschwür mit Zerfall im Centrum und unbedeutender Röthung in der Umgebung; es ist gegen $3 \mathrm{Cm}$. gross. Patient hat sich noch nie behandeln lassen, da er sich wohl fühlte. Im Harn viel Eiweiss, kein Quecksilber. Locale Behandlung der Geschwüre mit 1\% Carbolvaselin.

Am 8. October wurden zum ersten Mal $10 \mathrm{Ccm}$. Serum Nr. II eingespritzt, und bis zum 16. November $150 \mathrm{Ccm}$. in 15 Injectionen eingeführt. Die Körpertemperatur war die ganze Zeit hindurch normal und stieg nur selten am Abend auf $37^{\circ} \cdot 7^{\circ}$. Zuweilen bewirkten die Einspritzungen örtliche Schwellung und Schmerzhaftigkeit. Nach der dritten Einspritzung schwollen die Axillardrüsen an und wurden schmerzhaft; die Schwellung verschwand zugleich mit Sistirung der Einspritzungen.

Während der ganzen Zeit der Injectionscur blieb das Aussehen des knotigen Syphilids unverändert, die gummösen Geschwüre am Ellbogen bedeckten sich mit Krusten. Nach der 9. Finspritzung wurden locale compresses chauffantes verordnet, und danach reinigte sich das Geschwïr am Ellbogen. Am 16. November, nach 15 Einspritzungen, war das knotige Syphilid fast ïberall unverändert; das Geschwür am Ellbogen war kleiner geworden und in Vernarbung begriffen; die Ulceration am linken Knie war ebenfalls beinahe verheilt, mit Hinterlassung starker Infiltrate. Im Harn Quecksilberspuren. In Anbetracht der Erfolglosigkeit der Injectionscur wurden Quecksilberfrictionen und Jodkali verordnet; danach verheilten alle Geschwüre, und die Knötchen wurden mit Hinterlassung von Narben resorbirt.

Die Einspritzungen wurden in diesem Fall gut vertragen, Fieber war fast gar nicht vorgekommen, das Körpergewicht hatte während der Behandlungsdauer um 2 Kilo zugenommen. 
XVI. F. A., 14jähriger Bauer, schwarzhaarig, mager, schwächlich gebaut, $147 \mathrm{Cm}$. hoch, 34.8 Kilo schwer, aufgenommen am 16. October 1896.

Patient gibt an, sein Vater sei vor einem Jahr gestorben, seine Mutter gesund, von 4 Geschwistern habe die zweite Schwester auch Geschwüre an Händen und Füssen gehabt, die übrigen seien gesund. Er erinnert sich nicht als Kind krank gewesen zu sein. Seiner Meinung nach hat seine jetzige Krankheit vor drei Jahren begonnen, als er anfing Schmerzen in den Füssen zu empfinden und Geschwüre am rechten Oberschenkel und später am Ellbogen auftraten; er kam in diesem $\mathrm{Zu}$ stand nach Petersburg and wandte sich an das Marienhospital, wo man ihm ein Pflaster und Jodkali gab. Danach verheilten die Geschwüre rasch, aber die Schmerzen in Händen und Füssen vergingen nicht und störten ihn bei der Arbeit. Später begannen sie sogar anzuschwellen.

Bei der Aufnahme wurde constatirt: Schwächlicher Körperbau, mittelmässige Ernährung, geringer Fettpolster. Trotz seiner 14 Jahre sieht Patient wie ein zehnjähriger Knabe aus, kein Haarwuchs am Unterleib, ganz unentwickelte, haselnussgrosse Testikel, wie zu 7 Jahren. Die Vorderzähne sind dolchförmig; auf dem rechten Ohre ist Patient schwerhörig in Folge einer in der Kindheit durchgemachten Erkrankung. Am oberen Theil des rechten Oberschenkels und am rechten Ellbogen gezackte grosse, im Centrum entfärbte, an der Peripherie pigmentirte Narben. Die Knochen der Vorderarme und Unterschenkel sind höckerig, auf das 2-3fache verdickt und nach aussen verbogen (en lame de sabre). Einzelne Höcker, besonders an den Unterschenkelknochen, ragen weit hervor, sind mit normaler Haut bedeckt, im Centrum etwas erweicht und gegen Berührung ungemein empfindlich; dagegen ist die gleichmässige Verdickung der Knochen sehr hart und schmerzlos. Das Sternalende des rechten Schlüsselbeins ist ebenfalls verdickt und schmerzlos. Im Harn ist Eiweiss vorlanden; Quecksilber ist darin nicht nachweisbar. Patient klagt über nächtliche Schmerzen in den Armen und Beinen, die ibm den Schlaf rauben. Der mitgetheilte Befund ergibt die Diagnose: Syphilis hereditaria; osteoperiostitides gummosae.

Am 23. October wurden zum ersten Mal $10 \mathrm{Cem}$. Serum Nr. III eingespritzt und im Ganzen bis zum 17. November $70 \mathrm{Ccm}$. in 7 Injectionen. Die Körpertemperatur war nach den ersten drei Einspritzungen fieberhaft und stieg Abends auf 38.7-39.1", Morgens auf $37 \cdot 5-37 \cdot 8^{0}$; die nächsten vier Eirispritzungen hatten ebenfalls Fieber zur Folge, aber mit geringerer Temperatursteigerung. Fast alle Einspritzungen bewirkten örtliche Reaction in Gestalt von Röthung, Anschwellung und Schmerz an Stelle derselben; diese Erscheinungen verschwanden dann am nächsten Tag. Nach der 3. Einspritzung trat an den Unterschenkeln und Händen juckendes Erythem auf, das später in Purpura überging und nach einer Woche verschwand. Nach 4 Einspritzungen schwollen beiderseits die Axillardrüsen an und wurden sehmerzhaft. Das Körpergewicht betrug vor Beginn der Einspritzungen $36^{\circ} 0 \mathrm{Kg}$., nahm dann während des Fiebers 
unbedeutend - um $0.6 \mathrm{Kg}$. ab - und kehrte zum Schluss der Injectionen zur früheren Höhe zurück.

Im Verlauf der syphilitischen Erscheinungen waren während der Behandlung mit Einspritzungen keine bemerkbaren Veränderungen wahrzunehmen. Die Schmerzen in den Beinen wurden anfänglich etwas schwächer, obgleich die Periostitiden beim Befühlen ebenso schmerzhaft blieben.

14. XI. Nach der 6. Einspritzung. Die Schmerzhaftigkeit der Periostitiden und ihre Erweichung an den Unterschenkelknochen hat bedeutend zugenommen; das Fieber dauert fort.

20./XI. Nach 7 Einspritzungen. Die Erweichung hat noch mehr zugenommen, und die Haut über den Knötchen ist geröthet, so dass hier Aufbruch der Gummata zu befürchten ist; diejenigen an den Oberextremitäten blieben zwar unyerändert, aber Anfühlen der Höcker war auch hier etwas schmerzhafter als früher, und die nächtlichen Knochenschmerzen dauerten fort. Der Allgemeinzustand hat sich in Folge des Fiebers verschlimmert, der Appetit bemerkbar abgenommen. Im Harn noch immer Eiweiss, auch schwache Quecksilberspuren. Allgemeiner Kräfteverlust.

In Anbetracht geschilderter Erscheinungen wurden die Einspritzungen sistirt und gemischte Quecksilber Jodbehandlung verordnet; Patient bekam 30 Frictionen und gegen eine Unze Jodkali. Danach verschwand das Fieber, die erweichten Gummata an den Beinen wurden resorbirt, die Höckerbildung nahm in bedeutendem Masse ab, die Schmerzen in den Armen und Beinen hörten auf, die Kräfte kehrten wieder, und Patient fühlte sich wohl, als er entlassen wurde.

Auch in diesem Fall wurden die Erwartungen hinsichtlich der Heilkraft der Seruminjectionen getäuscht. Die dolores osteocopi nocturni vergingen nicht, die syphilitischen Erscheinungen machten Fortschritte; es war Aufbruch der gummösen Periostitiden zu befürchten. Ausserdem musste die Anwendung der Injectionen aufgegeben werden, da im Gefolge derselben starkes Fieber, Erythem, Schmerzen an der Einspritzungsstelle und Verschlimmerung des Allgemeinzustandes eintraten. 